
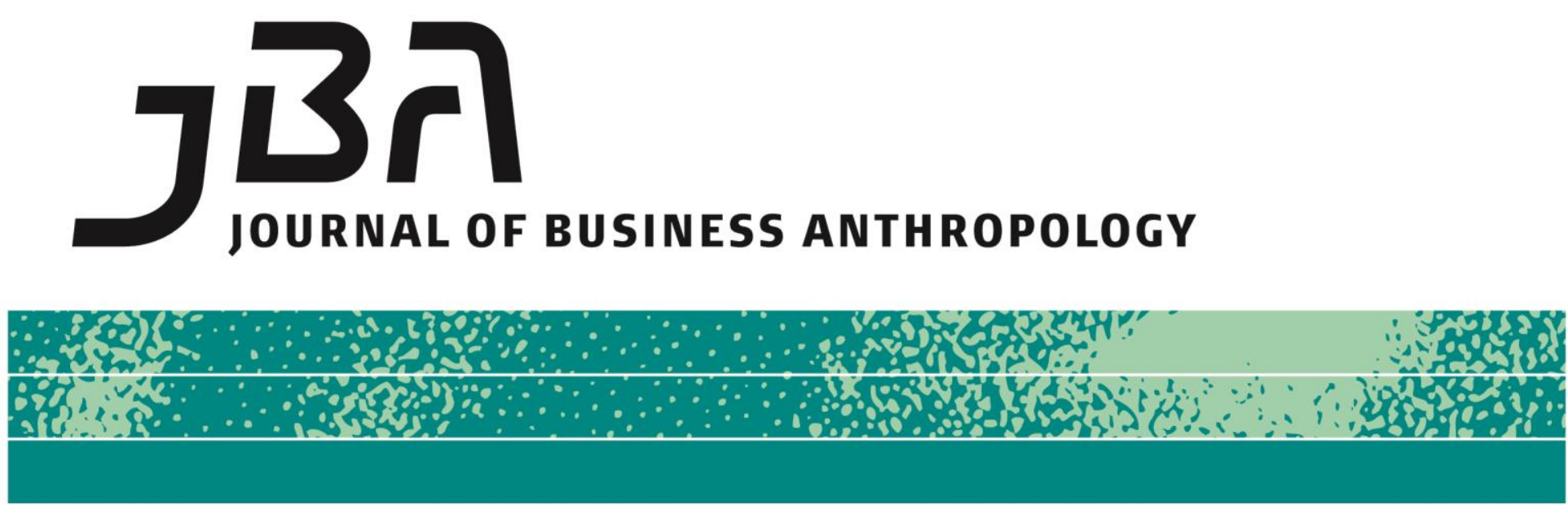

\title{
A Reconsideration of Middle Eastern Islamic Bank Practices in Malaysia
}

\author{
Hideki Kitamura
}

\begin{abstract}
Middle Eastern Islamic banks' contributions to product development in Malaysia have been frequently highlighted; nonetheless, there has been a research gap on the adaptation of foreign Islamic banks to the Malaysian market. This study examines this aspect through a case study of the practices of Kuwait Finance House Malaysia Berhad (KFHMB) among these foreign banks. The results of this exploration highlight the impact of Malaysian business customs and culture on KFHMB's banking product selection, especially on the retail banking side. The findings herein imply that regional differences in products between Malaysia and the Middle East derive from differences in market environments rather than from mere differences in Islamic jurisprudence, as previous studies claim. Ultimately, this study asserts the value of an ethnographic approach to studying Islamic banks' adaptation to foreign markets, especially considering the KFHMB's dilemma of facing religious ideals versus market realities.
\end{abstract}

Page 1 of 22 JBA 9(1): 66-87 Spring 2020

(C) The Author(s) 2020 ISSN 2245-4217

DOI: $\underline{10.22439 / j b a . v 9 i 1.59}$ $\underline{67}$

\section{Key words}

Islam, Islamic banking, Kuwait Finance House Malaysia Berhad, Malaysia, ethnography. 


\section{Introduction}

Since Bank Negara Malaysia (BNM), the central bank of Malaysia, embarked on the liberalization of Islamic banking licenses in the early 2000s, three Middle Eastern Islamic banks have started to provide services in the country: the Kuwait Finance House Malaysia Berhad (KFHMB), the Al Rajhi Banking \& Investment Corporation Malaysia Berhad (Al Rajhi), and the Asian Finance Bank Berhad (which was absorbed by the Malaysia Building Society Berhad on February 7, 2018). These foreign Islamic banks introduced several Middle Eastern products to the Malaysian market. For example, in 2006, KFHMB introduced Musharakah Mutanaqisah (MM) (which is sometimes called "diminishing Musharakah") as a house financing product (Mohd Subky et al. 2017; Smolo and Hassan 2011). ${ }^{1}$ At that time, the most popular contract type in Malaysia for house financing was Bay' Bithaman Ajil (BBA), which was facilitated by the Islamic transaction of Bay' al-'Inah. Bay' al-'Inah is strictly prohibited in the Middle East, as Shariah scholars in the region consider it a "backdoor" to Riba, or the interest of conventional banking (Haron and Shanmugam 1997; Ismail et al. 2014; Laldin et al. 2012; Meera and Abdul Razak 2005; Rosly 2005). ${ }^{2}$ On the other hand, MM tends to be considered globally acceptable or an ideal type of house financing transaction, because it is based on profit-and-loss sharing-namely, partnership-based equity finance (e.g., Meera and Abdul Razak 2009; Mohd Subky et al. 2017; Shuib et al. 2011; Smolo and Hassan 2011). ${ }^{3}$ Another example of products introduced by foreign banks is Commodity Murabahah (CM) or Tawarruq. ${ }^{4}$ CM was first implemented in 2000 by a financial institution in Saudi Arabia (Nagaoka 2008), whereupon it came to prevail in the Middle East. In 2005, KFHMB introduced CM transactions

\footnotetext{
${ }^{1} \mathrm{MM}$ is a "contract of partnership that allows one (or more) partner(s) to give a right to gradually own his share of the asset to the remaining partners based on agreed terms" (Bank Negara Malaysia 2010: 221).

${ }^{2}$ Islamic scriptures prohibit the concept of Riba, which is normally construed in conventional banking as interest; thus, the prohibition of the use of interest in banking is one rationale for Islamic banking. "Conventional banking," in the common parlance, speaks to banking in which interest fees are collected; this term is normally used by both the Islamic banking literature and Islamic banking practitioners to distinguish between the two. While the concept of Bay' al-'Inah remains controversial, the BBA is more or less globally accepted and sometimes called Murabahah; this is broadly used by Islamic banks in the Middle East, such as Kuwait Finance House.

${ }^{3}$ Profit-and-loss sharing was highlighted as a foremost unique quality of Islamic banking by Islamic economists, many of whom proposed religious banking during the worldwide Islamic resurgence in the mid-20th century (Yousef 2004). Even today, Islamic economists strongly support the implementation of profitand-loss sharing in Islamic banking (e.g., Asutay 2012; Hasan 2011; Smolo and Hassan 2011).

${ }^{4}$ Because commodity Murabahah and Tawarruq are similarly structured, for the sake of convenience, we consider these terms interchangeable here. Strictly speaking, however, these two transactions differ in terms of their procedures (see Abdul Ghani and Hussain 2007).
} 
to the Malaysian market in cooperation with BNM (Bank Negara Malaysia 2006). CM is currently the most prevalent and flexible type of transaction used in liquidity management and various banking products in Islamic banking. As a globally accepted transaction, CM has replaced various Malaysian products facilitated by Bay' al-'Inah, although several scholars question the religious authenticity of this CM transaction (Abdul Ghani and Hussain 2007; Ismon 2012; Mahayudin et al. 2014; Mansour et al. 2015).

Overall, since the mid-2000s, several products-including those featuring MM and CM transactions-have been introduced by the Middle Eastern banks, especially KFHMB. Previous studies argue that these products compensate for regional differences in practices between Malaysia and the Middle East, thereby enabling Islamic banking to expand globally (e.g., Abdul Ghani and Hussain 2007; Nagaoka 2008). However, while previous studies tend to focus on the influence of foreign Islamic banks on Malaysian Islamic banking, foreign banks' adaptations to the Malaysian market have not been sufficiently explored-despite the potential value of such an exploration in terms of reconsidering frequently discussed regional differences between Malaysia and the Middle East. Given the religious issue of Bay' al-'Inah, inter alia, regional differences in practices have aroused controversy among scholars. Malaysian practices of this controversial transaction have resulted in the lingering image that Malaysia is relatively lenient vis-à-vis Shariah compliance, at least in comparison to the strict Middle East (e.g., Chong and Liu 2009; see also Khan and Bhatti 2008). ${ }^{5}$ Moreover, some explain regional differences in terms of the influence of the school of Islamic jurisprudence that dominates in each region (e.g., Mahmud al-Awan 2008; Zaher and Hassan 2001). Among the four schools of Islamic jurisprudence in the Sunni tradition, only the Shafie school permits Bay' al-'Inah: it is forbidden by the other three schools of Maliki, Hanafi, and Hanbali. ${ }^{6}$ The Shafie school predominates in Southeast Asia, and the use of Bay' al-Inah in the region has been justified by a Shariah endorsement of the Shafie view (Balala 2011; Rosly 2005). ${ }^{7}$ Many Islamic scholars acknowledge this

\footnotetext{
${ }^{5}$ The term "Shariah compliance" is used among scholars and practitioners of Islamic banking and finance to indicate the extent to which Islamic banks and their products and services adhere to Islamic law.

${ }^{6}$ As an example of the differences in religious views among the schools of Islamic jurisprudence, one can point to interpretations of Niyyah, or the intention of transaction. For the Shafie school, the intention is not significant; however, the other three schools assign considerable value to the intention, and this allows Middle Eastern scholars to disallow Bay' al-'Inah, as there is no real intention to use the traded assets (Rosly 2005).

${ }^{7}$ The influence of the schools of Islamic jurisprudence over society can be identified geographically. For example, the Maliki school spread in North Africa (e.g., Libya, Tunisia, and Morocco), while the Hanafi school is influential around Egypt, Syria, Iraq, and Turkey. According to Muhammad (2008), the first Islamic civil law-known as Al-Ahkam al-Adliyah in Egypt, Syria, Iraq, Turkey, and
} 
factor in the implementation of Bay'al-'Inah (see Khan and Bhatti 2008; Nagaoka 2007), and social scientists also tend to take for granted the influence of Islamic jurisprudence on regional differences (e.g., Poon et al. 2017; Warde 2000; see also Lai 2015).

However, as a matter of course, Islamic banks must adhere not only to a theological legal system but also to the secular legal system for the banking industry, just as conventional banks do. Furthermore, the transaction culture involving other market participants would be unique to each market, and this would naturally affect Islamic banking practices. When entering a different market, it would not be easy for Islamic banks to simply use their preferred banking products without modification. Considering the influence of market particularity, more research attention needs to be diverted to how the three foreign Islamic banks adapt their practices to the Malaysian market.

This study looks to explore this adaptation process, and to this end, it conducts a case study of KFHMB practices, given that previous studies tend to stress the bank's contribution to changes in the product offerings in Malaysian Islamic banking. Moreover, some of those previous studies argue that KFHMB prefers to use products and services that its parent bank, Kuwait Finance House (KFH), uses in the country, and views of the bank's Shariah committee are paramount to the views of the Shariah Advisory Council of Bank Negara Malaysia (SAC), the highest authority for all Shariah issues in Islamic banking and Takaful (Islamic insurance) in Malaysia (e.g., Rosly 2017; Shuib et al. 2011). ${ }^{8}$ Islamic banks in Malaysia are obligated to follow SAC guidelines, and they are allowed to adopt only views that are stricter than those of the SAC. According to Mahmud al-Awan (2008), whenever there has been a clear difference in Shariah opinions between SAC and the bank's Shariah committee, KFHMB has adopted its committee's view, as it assigns great value to the corporate governance of the KFH Group. Considering KFHMB's persistence in adhering to its own style of Islamic banking practices, it is no doubt valuable to examine the extent to which KFHMB persists in its own practices within the context of the Malaysian market.

Furthermore, the potential value of an inquiry into the adaptation process is significant in both anthropological and sociological terms. First, such an inquiry would contribute to the debate concerning the dichotomy between transnational and localizing forces. For example, anthropologists

Jordan-was codified on the basis of the views of the Hanafi school, which predominates in the region.

${ }^{8}$ Each Islamic bank usually has a Shariah supervisory body that consists of Muslim religious scholars; this body ensures and enhances the Islamic quality of the bank's products and services. This body examines all proposed products prior to market introduction. In several countries - such as Malaysia-the statutory body of the central bank is considered the highest Shariah authority; its religious views are typically considered foremost, superseding the views of any Shariah board of any Islamic financial institution in the country. 
ethnographically explore how a transnational corporation, McDonald's, assimilated into local food cultures in Asia, despite the common assumption that transnational corporations "force" other countries to accept their universal or transnational standard (i.e., Western values) in an act known as cultural imperialism or McDonaldization (Watson 2006 [1997]). In the context of KFHMB practices, while previous studies highlight the consistency of the transnational force of the KFH Group in a different environment—namely, Malaysia (e.g., Rosly 2017)—the current study seeks to explore KFHMB's process of adapting to the Malaysian market. In so doing, I make inquiries into whether the practices of the KFH Group have been transnationally adopted even in Malaysia, or whether indigenously embedded market forces in Malaysia have influenced KFHMB practices. Second, in contemporary economic sociology and organizational studies, there is a lingering debate about how economic behavior is created in the course of antagonistic relations between inherently constraining institutional forces and individual creativity; this research has manifested as the theoretical dichotomy between new institutionalism, which seeks to explain collective behavior through institutional mechanisms, and constructivism, which assigns value to the creativity of actors (Fligstein and McAdam 2012; Granovetter 2017). The current case study of KFHMB's adaptation process examines the extent to which organizational behavior is autonomous from institutional logics, such as environmental conditions that institutionalists assume to be influential in shaping organizational behavior. Thus, this ethnographic exploration would contribute to the debate between new institutionalism and constructivism as an empirical case that demonstrates how institutional forces and actors' agency work in making organizational behavior.

Since this study aims to ethnographically explore KFHMB's adaptation process, I undertook interview-based research with KFHMB practitioners and with other persons concerned. The participants were identified through snowball sampling, and each interview (duration: 90180 minutes) was conducted as a semi-structured face-to-face interview.

\section{How did foreign banks adapt to the Malaysian market culture?}

\section{An Overview of Kuwait Finance House}

KFH was established in 1977 as the first Islamic bank in Kuwait. The bank adopted a trading approach in its financial services provision. For example, for car financing, it would hold cars in its showroom as stock to sell to customers while using an installment financing scheme because $\mathrm{KFH}$ in its financing assigned considerable value to actual buying and 
selling (Kuwait Finance House 2010; Smith 2004). ${ }^{9}$ Interestingly, it is often said that its trade-like financial service approach derived from the fact that the bank was established by a consortium of traders. According to a BNM official, KFH's special approach to Islamic banking was a key reason why BNM chose $\mathrm{KFH}$ as the first foreign Islamic bank in Malaysia. That official says that:

When proposals for licenses were submitted to us, we asked all the applicants what they could bring to us. Of course, the first thing is capital, then, employment and products. When we talked with Kuwait Finance House, they were creative in their own country so we hoped [for] their presence here. We hoped they introduced some innovative subjects to here. ... I think, even in the Middle East, only a few banks behave differently from our banks, like Kuwait Finance House. Kuwait Finance House is special in this point. They were not regulated by the central bank initially so they could do more things than what other Islamic banks can do. Kuwait Finance House is now regulated under the central bank and their behavior also changed because they have to adjust to [a] new regulation and [a] new environment, but they can still do a lot of [trade-like financing business]. When I went to Kuwait to understand their business model, they really behaved like [a] trader. They have properties, auto, and commodit[ies] to provide the facilities in their finance (personal communication, December $20,2017)$.

As the BNM official says, $\mathrm{KFH}$ had been registered simply as a commercial bank until May 24, 2004, when Central Bank of Kuwait (CBK) redefined KFH as an Islamic bank (Kuwait Finance House 1981; Kuwait Finance House 2010). In Kuwait, there had been no special legal framework for Islamic banks until the CBK modified in 2003 the existing legal framework for conventional banks; meanwhile, Islamic investment companies have been under the jurisdiction of the CBK since the early 1990s. As reflected in the legal framework introduced in 2003, CBK considers Islamic banking an integral part of the banking industry (The Central Bank of Kuwait 2005; The Central Bank of Kuwait 2007). Accordingly, since then, CBK started to require Islamic banks to perform a similar function to that of conventional banks. A KFHMB banker (personal communication, May 20,2018) says that KFHMB moved towards liabilitybased products on account of an internal change in its parent bank, KFH, which had derived from being placed under CBK's supervision. KFH's practices changed to some extent as of the mid-2000s; nonetheless, $\mathrm{KFH}$ has not abandoned its trade-like approach and remains unique among worldwide Islamic banking practices.

\footnotetext{
${ }^{9}$ See also the KFH homepage URL: https://www.kfh.com/en/cars/AutoFinancing-New/New-Cars.html.
} 


\section{Malaysia's Invitation to Foreign Islamic Banks}

According to an Islamic banker who has worked for two of the three foreign Islamic banks, when the three foreign Islamic banks were invited to Malaysia, BNM held a meeting session between representatives of the foreign banks and local prominent Islamic bankers. That banker says that:

In 2005, some local Islamic bankers at the invitation of Bank Negara [BNM] talked with three foreign Islamic banks. For example, one of the pioneers of Bank Islam was there probably because he had [a] connection to Middle Eastern banks. ${ }^{10} \mathrm{He}$ talked with the chairman of Al Rajhi, [the] Qatar Central Bank governor, and [the] Kuwait Finance House chairman. Asian Finance Bank was owned by three countries and [the] main shareholder was Qatar, but behind Qatar there [were] Yemeni. Qataris' portion was also shared by Yemeni. In the process of the establishment of a new bank, you apply to [the] central bank with the plan of your shareholders so you get first principal approval. After the principal approval is given, [you] normally [need] six months [...] to set up and start operation, but [the] Asian Finance Bank was delayed simply because they consisted of three countries. They couldn't find a meeting point. [...] The Yemeni representative, one of the shareholders, knew the pioneer of Bank Islam. So, he approached the pioneer to help the establishment. The pioneer invited me to join the working team to set up. I became the first secretary and the first staff [member]. The Yemeni representative and the pioneer became the first cofounding directors. [...] When we finished all the preparations, Bank Negara gave [the] approval to start the operation. The bank took almost two years to launch the operation in 2007 (personal communication, May 8, 2018).

Without local bankers' support, the Asian Finance Bank could not create a compromise among the shareholders, simply because they comprised a consortium of several banks. Meanwhile, according to a pioneer of KFHMB (personal communication, May 20, 2018), the KFHMB prepared for operations in Malaysia under its corporate identity as the KFH Group. While appointing many local employees to its board and to various management positions, it mobilized its own human resources into some key positions, to maintain consistency as part of the KFH Group. Interestingly, several local individuals-many of whom had no experience in Islamic banking-joined the pioneering team. However, KFH appointed its own staff as managing director and head of the Shariah division, and the members of the Shariah committee were mobilized through its own

\footnotetext{
${ }^{10}$ Bank Islam Malaysia Berhad, established in 1983, was the first Islamic bank in Malaysia.
} 
human resources in order to comply with its Shariah criteria and with its corporate identity in Kuwait. After KFHMB was given an Islamic banking license on May 8,2005, its first branch commenced operations in August 2005, two years earlier than the Asian Finance Bank.

It was most important for KFHMB to have qualified Shariah staff who could help the bank maintain KFH's style of Islamic banking in a different environment-namely, the Malaysian Shariah governance system, which differed from that of Kuwait and other Middle Eastern countries. For example, there are some differences in the role of the Shariah supervisory body between Malaysia and the Middle East. Shariah supervisory bodies in Middle Eastern Islamic banks are empowered to decide whether products can be introduced to the market in Islamic terms. On the other hand, Malaysian Islamic banks need to obtain approval from SAC for new products, since that gatekeeping role is entrusted to SAC as the highest authority over all Shariah issues in Islamic banking. ${ }^{11}$ Given these differences in Shariah governance systems, in Malaysia, the Shariah supervisory bodies of commercial Islamic banks are now called Shariah "committees," whereas their analogous counterparts in Middle Eastern countries are called Shariah "boards." (For example, KFH in Kuwait calls its body the "Fatwa and Shari'a supervisory board," whereas in Malaysia, KFHMB calls its body the "Shariah committee.") While KFH can introduce new products in accordance with the views of its own Shariah board, when developing new product offerings, KFHMB is compelled to reconcile the views of its own Shariah committee with those of the SAC. To deal with these differences in governance systems, KFHMB needed talented Shariah staff who could reconcile the views of its Shariah scholars with those of SAC and thus help the bank implement its own style of Islamic banking in Malaysia.

\section{KFHMB's Adaptation to Malaysia}

Previous studies contend that KFHMB assigns great value to the views of its own Shariah committee (e.g., Mahmud al-Awan 2008; Rosly 2017; Shuib et al. 2011). The bank sought to implement its own style of Islamic banking in accordance with the views of its Shariah committee-unless those views run counter to Malaysian law or SAC Shariah requirementsby employing Shariah staff who could assist the bank in translating its ideals into business in the Malaysian market. When KFHMB started its operations in 2005, most of the banking products in Malaysia were not acceptable to the members of its Shariah committee. What the bank first did was introduce several new products that could meet the Shariah

\footnotetext{
${ }^{11}$ Since the 2010s, some Middle Eastern countries, such as Oman and the United Arab Emirates, have started to adopt Malaysia's Shariah governance model (see Bouyamourn 2016).
} 
criteria of the bank's Shariah committee.

\section{a. Commodity Murabahah}

$\mathrm{CM}$-in which a customer can obtain cash on the spot through the sale of a commodity with a bank and commodity brokers (see Figure 1)-is often said to be KFHMB's most significant contribution to the Malaysian market. As Rosly (2017) points out that the three foreign Islamic banks have excess liquidity owing to the insufficiency of banking products available to them, KFHMB initially experienced liquidity management challenges. One of the reasons for the liquidity issue was because the dominant transaction for liquidity management in Malaysia was Bay' al'Inah, where a customer sells an asset to a bank for cash on the spot and buys it back shortly thereafter at a mark-up on a deferred payment basis (see Figure 2); such a transaction was unacceptable to KFHMB and to the other foreign Islamic banks (see Rosly 2005). To resolve this liquidity issue, CM was introduced by KFHMB as an alternative to Bay' al-'Inah. Since the introduction of CM in 2005, the BNM has developed an infrastructure for CM transactions. For example, while Middle Eastern Islamic banks use the London Metal Exchange as the commodity trading platform, Malaysia established a new platform for CM transactions called Bursa Malaysia Suq Al-Sila, where a popular Malaysian agricultural commodity, crude palm oil, is used for CM transactions (Ismon 2012). Following the establishment of infrastructure that could accommodate CM transactions, CMs prevailed extensively in Malaysian Islamic banking. SAC then issued a Shariah resolution in 2012 that imposed strict conditions for Bay' al-'Inah transactions, and Islamic financial institutions have gradually converted all Bay' al-'Inah-based products into CM-based ones (Bank Negara Malaysia 2012; Mahayudin et al. 2014). Thus, with the introduction of CM, Malaysian Islamic banks were able to make their practices more similar to those of Middle Eastern banks, as envisaged by the BNM (Bank Negara Malaysia 2007).

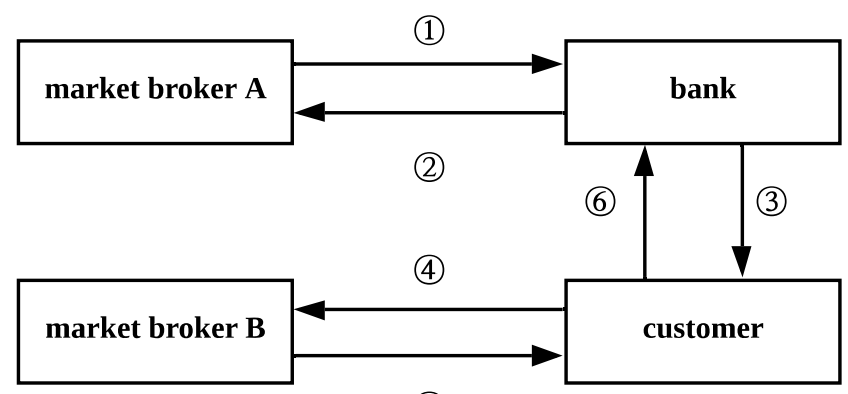

(5)

\section{Figure 1. Commodity Murabahah}

Notes: 1 . Sale of a commodity to a bank. 2. Immediate payment to the broker in cash. 3. Resale of the commodity to a customer. 4 . Sale to another broker. 5. Receipt of cash. 6. Deferred payment in installments with a mark-up. 


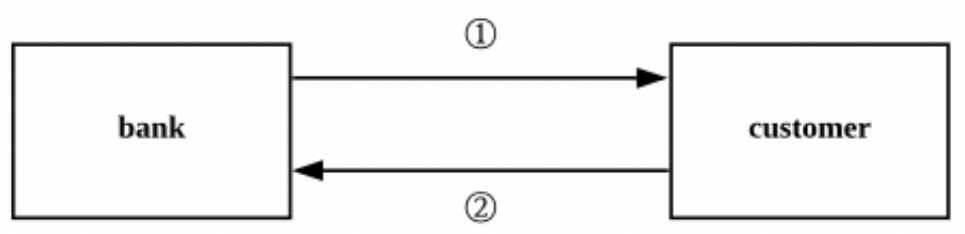

Figure 2. Bay'al-'Inah

Notes: 1 . Sale of an asset owned by a bank to a customer who needs cash, through a deferred payment with mark-up. 2 . The bank buys back the same asset from the customer with a lump-sum payment.

\section{b. Musharakah Mutanaqisah}

KFHMB introduced MM (see Figure 3) to the Malaysian market, which many scholars consider a house financing transaction preferable to BBA, a popular house financing product in Malaysia at the time that was facilitated by Bay' al-'Inah (see Figure 4). MM is widely used in the Middle East and in Western countries such as Australia and the United Kingdom. BBA, on the other hand, has been adopted only in Southeast Asian countries such as Malaysia, Indonesia, and Brunei, as Shariah scholars elsewhere basically disapprove of it. Islamic economists argue that MM is not only more religiously ideal than BBA, but also more profitable for customers (e.g., Meera and Abdul Razak 2005; Meera and Abdul Razak 2009). Thus, the introduction of MM to Malaysia was welcomed by Islamic economists and Shariah scholars, as it helped promote Malaysia as a global hub of Islamic banking, which was a BNM's rationale for inviting foreign Islamic banks (Smolo and Hassan 2011).

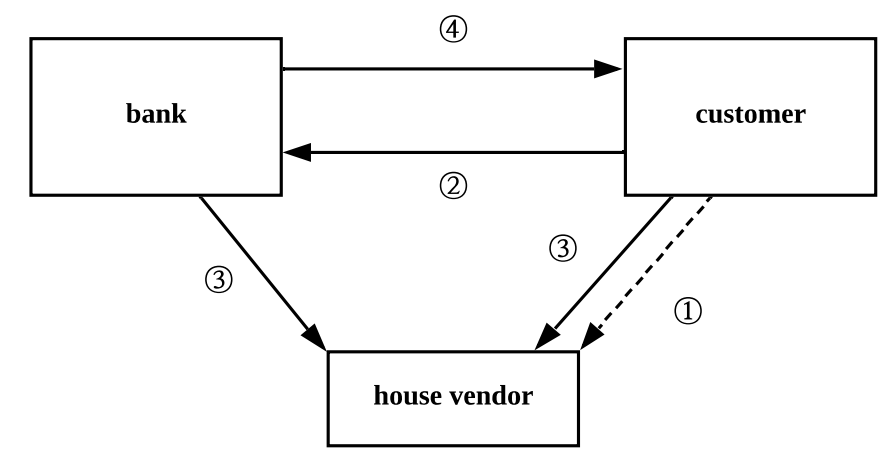

Figure 3. Musharakah Mutanaqisah (MM)

Notes: 1. A customer identifies a house. 2. The customer makes MM contract with a bank, with the promise to purchase the bank's share of the house. 3 . The customer buys the house in partnership with the bank, and the payment is conducted in accordance with a predetermined ratio (e.g., bank pays 90 percent and customer pays the balance). 4. Lease the bank's share of the house to the customer, and the contract matures when all the bank's share is transferred to the customer. 


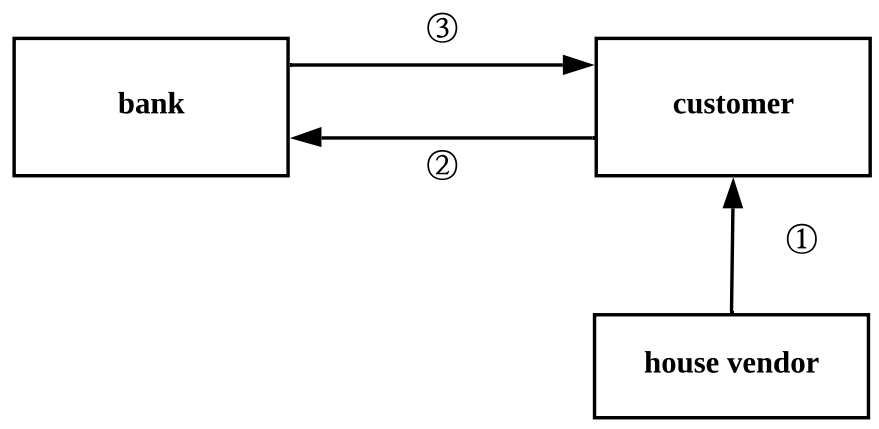

Figure 4. BBA house financing facilitated by Bay' al-'Inah

Notes: 1. A customer enters into a purchase contract with a house vendor. 2. As a formality, the customer sells the house to a bank for cash to settle the purchase contract with the house vendor. 3 . The bank sells the house back to the customer in installments with a mark-up.

The BNM prepared a legal framework for the smooth execution of MM transactions; one such preparation involved the exemption of extra tax that would be otherwise charged in MM transactions, but never accrue on other Islamic house financing products, such as BBA (Smolo and Hassan 2011). However, despite receiving the religious support of Shariah scholars and legal assistance from the BNM, MM transactions did not function well in Malaysia. According to Mohd Subky et al. (2017), most Islamic banks in Malaysia discontinued the provision of MM house financing, owing to several problems; these problems included documentation costs, the high risk assumed by banks, and interestingly, the high rate of property project abandonment in the country. A practitioner at a local Islamic bank stresses the influence of property project abandonment on MM viability:

The problem was because of property and construction. In the case of [the] under-construction of property, in Musharakah Mutanaqisah, [the] bank and customer have ownership of property. When the property is abandoned and not completed, who take[s] the ownership to pay back to [the] bank? Because part of [the] property belongs to [the] bank, and [a] certain percentage belongs to [the] customer. So, it comes to conflict. That's why we moved to commodity Murabahah. If the bank uses commodity Murabahah for house financing, the asset used in financing is a commodity, crude palm oil, [and] not property itself. You can see some abandoned project[s] in Malaysia. So, it's not suitable for [the] Malaysian environment, but for [a] completed property, we can still adopt Musharakah Mutanaqisah (personal communication, October 4, 2018).

In fact, the abandonment of property projects has been a serious problem in Malaysia since the 1980s, and, in 1990, the BNM set up the 
"Abandoned Housing Project Fund" to provide special assistance with respect to abandoned housing projects (Abdul Rahman et al. 2013). Even recently, the Minister of Housing and Local Government stated that there were an estimated 350 abandoned housing projects in Malaysia in 2018 (Anonymous 2018). Moreover, an Islamic banker (personal communication, October 11, 2018), who had worked at KFHMB and is now working in Kuwait, refers to the unique nature of the Malaysian property sales model as a setback in implementing MM transactions. In Malaysia, developers sell properties before their construction even commences; in comparison, in several countries, properties are also sold upon completion of construction (i.e., the "Build then Sell" model). The Malaysian "Sell then Build" model exposes property buyers to high risk, especially in the event of developer failure. In the Malaysian legal system, buyers cannot take legal action against in-default developers; this allows irresponsible developers considerable room to easily abandon projects at any stage or when a potential loss is expected (Abdul Rahman et al. 2013).

For these reasons, the Malaysian property sales model made it difficult for Islamic banks to implement MM transactions. In fact, the OCBC Al-Amin Bank Berhad does not employ MM for under-construction properties (Mohd Subky et al. 2017). Moreover, although KFHMB took the initiative of introducing MM transactions in Malaysia, the bank discontinued its provision and instead adopted another transaction for house financing. The aforementioned ex-KFHMB banker (personal communication, October 11,2018) mentions the inherent difficulty in managing the processes of MM transactions as another reason for their discontinuance. Since the bank's technical system could not be customized to manage MM transactions, KFHMB manually controlled for it. This technical issue arose partly because KFH does not use MM in Kuwait, as there is currently no mortgage law in Kuwait and property financing is done through either personal financing for individuals or term financing for corporate customers. Overall, $\mathrm{MM}$ - as a transaction type advocated by Shariah scholars and Islamic economists-has not worked well in Malaysia.

\section{c. The Conversion of Car Financing Products}

As mentioned, in Kuwait, KFH holds cars as assets in its showrooms for financing. Its car financing method is typical of the Murabahah transaction (i.e., a sale with a mark-up) in Islamic economic theory, and the KFH's financing profits are religiously certified as necessary brokerage. KFH has since its establishment in 1977 employed this transaction type for car financing. To ensure consistency within the KFH Group, KFHMB sought to provide the same car financing product (see Figure 5); however, according to a pioneer of KFHMB, the bank faced legal issues in Malaysia and had to modify the structure of its car financing product. That KFHMB pioneer says that: 
Unfortunately, KFHMB ran into some legal and regulatory challenges. For example, banks in Malaysia aren't allowed to acquire property directly in the form of an asset portfolio to warehouse and sell to customers. The completely knocked-down (CKD) sectors are well established with all the motorcar companies having assembly plants in Malaysia, their own sophisticated distribution network as well as offering their own financing to their buyers. Besides, the auto industry in Malaysia has an approved permit (AP) system in place to import completely built-up (CBU) cars. The only way the bank could enter the space was to partner with approved permit (AP) holders. The bank thus entered into an agreement with automobile dealers who themselves had a network of AP dealers (personal communication, May 27, 2018).

1. buy car and stock it in the bank's showroom

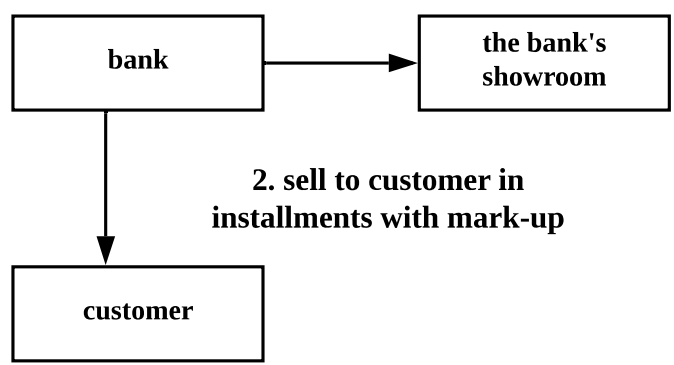

Figure 5. Structure of KFH's car financing process

Foreign automobiles have predominated in the Malaysian automobile market since state independence in 1957. The first national automobile company, Perusahaan Otomobil Nasional Berhad (National Automobile Enterprise), commonly called Proton, was established in 1983 as part of an ambitious national car project led by Prime Minister Mahathir. The project was expected to improve the indigenous Malay presence in the car industry (Leutert and Südhoff 1999). Although the second national car manufacturer, Perusahaan Otomobil Kedua Sendirian Berhad (Second Automobile Enterprise), called Perodua, was set up in the early 1990s, the predominance of foreign cars in the Malaysian market did not change in the ensuing years. In that context, the AP system was introduced to protect the interests of local automobile manufacturers, by imposing an extra cost on imported foreign cars. Nonetheless, despite the government's protective policy in favor of local cars, the demand for foreign cars remains high compared to local ones (Islam et al. 2016).

APs are import and export licenses issued by Permit Issuing Agencies as per the Customs Act of 1967. All vehicles, regardless of being 
CBU or CKD, can be imported only by AP holders. ${ }^{12}$ Thus, the automobile market is substantially controlled by AP holders and the car dealers who work in partnership with them. To continue its own style of car financing under the structure of the Malaysian car market, KFHMB decided to enter into partnership with a few car dealers who were in alliance with AP holders (see Figure 6). However, the modified car financing structure did not work. What is worse, the partnership dealers tricked KFHMB by abusing a loophole in the partnership contract and, as a result, the bank suffered losses. The aforementioned pioneer of KFHMB says:

We tested a few partnerships. In the partnership, we paid for customs clearance and then physically stored the cars at the respective dealers for the dealers to sell. However, as the dealer was not bearing any cost of those cars, they themselves were not serious in selling them to prospective customers. Their priority was to dispose of their own stock, which was being financed by their banks. So, KFHMB's cars remained unsold. Furthermore, no registration card (title deed) is issued for such imported used cars until they are sold to a buyer, thus the bank couldn't legally register its claim on the asset. Instead, it entered into a "master agreement" arrangement with the dealers, but what happened was [that] without the bank's approval, either the cars were switched or even disappeared due to the lack of a legal claim on the car. The reason why the registration card is only issued once the car is purchased by the end buyer is [that], as soon as it is issued, the car would be considered "sold" and its value depreciated. So, to maintain the value of the car, no registration card is issued until a buyer takes it. We pretty much had to rely on trust in dealing with them, but the scheme did not work. Unfortunately, the bank suffered losses through this arrangement (personal communication, May 27, 2018).

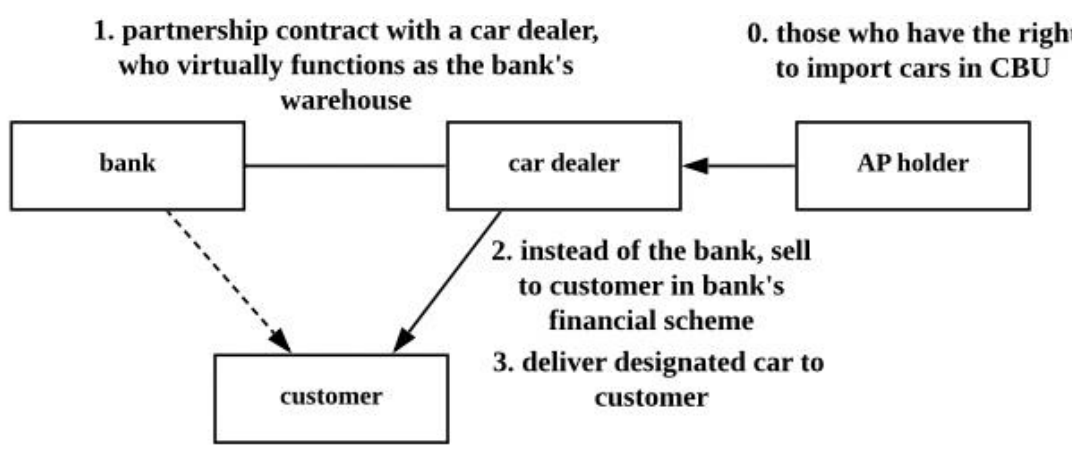

Figure 6. KFHMB's modifications to the structure of the car financing process

Notes: AP: approved permit; CBU: completely built-up

\footnotetext{
${ }^{12}$ See the Ministry of International Trade and Industry homepage. URL: https://www.miti.gov.my/index.php/pages/view/3796
} 
Shortly after testing the partnership contracts with car dealers, KFHMB converted its car financing product into another product facilitated by an al-Ijarah Thumma al-Bay' (AITAB) transaction-a transaction type that most of the Malaysian Islamic banks use (see Figure 7). As is evident in the above cases of MM discontinuance and the conversion of its car financing product, KFHMB experienced several "trials and errors" in determining which products would fulfill both Malaysian market requirements and the Shariah requirements of its Shariah committee scholars-especially on the retail banking side, where other market participants (e.g., car dealers and property developers) are involved in financial transactions.

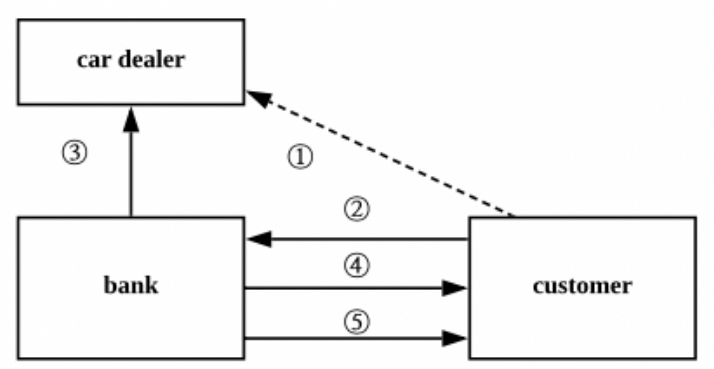

Figure 7. Structure of the AITAB car financing process

Notes: 1 . A customer identifies a car. 2. The customer makes a lease contract with a bank. 3 . The bank purchases the car. 4 . The bank rents the car to the customer. 5 . The bank sells the car upon the maturity of the lease contract.

In the first five years, KFHMB concentrated mainly on corporate and investment banking, and retail banking accounted for only a small percentage of the bank's total assets. Since investment banking is more susceptible to economic fluctuations than is retail banking, the bank has since 2010 shifted its efforts toward retail banking (Anonymous 2010). According to the above pioneer of KFHMB (personal communication, May 27, 2018), while its parent bank is the second-largest bank in Kuwait (behind the National Bank of Kuwait) and has a strong presence in both retail and wholesale banking, KFHMB was determined to focus initially on wholesale banking. This decision stemmed not only from its desire to quickly establish a market presence in Malaysia, but also from its strategy to wait and see, prior to expanding its retail banking, whether its retail banking products would be embraced by the Malaysian market. During that five-year period, KFHMB used CM transactions, particularly for serving corporate customers-likely because CM transactions involve only commodity brokers (except for customers), which thus allows banks to complete the entire transaction without involving other market participants. This characteristic distinguishes $\mathrm{CM}$ transactions from several retail banking transactions, such as MM and KFH's original car 
financing. Following its five-year retail banking experiment, KFHMB embarked on a diversification strategy by which it sought by 2015 to have retail banking represent 40 percent of its assets and liabilities. Thus, for KFHMB, the first five years were all about "trials and errors" with respect to its retail banking products in Malaysia, where the bank's products were basically uncommon.

\section{Conclusion and Discussion}

This study ethnographically explored the adaptation process of KFHMB to the Malaysian market. It verified that KFHMB needed to change its car financing product on account of the problems that it faced in building appropriate and successful partnerships with car dealers. Despite KFHMB's efforts to implement its own style of Islamic banking, the attempt did not bear fruit. The bank had no choice but to use the same product as local Islamic banks. Moreover, both the high rate of property project abandonment and the Malaysian property sales model affected the viability of Musharakah Mutanaqisah (MM) transactions; at that point, most Malaysian banks-including KFHMB-discontinued the use of this product, despite MM transactions having the full support of Shariah scholars and Islamic economists (Smolo and Hassan 2011).

The findings highlight the impact of Malaysia's unique business culture on KFHMB's product offering-especially on the retail banking side, where business relationships with other market participants influence the implementation of banking transactions. The implication is that regional product differences between Malaysia and the Middle East derive not only from differences in Islamic jurisprudence or piousness, but also from differences in market environments. Moreover, in anthropological and sociological terms, the results indicate that Malaysian institutional logic (or indigenously embedded market force) functioned well and was influential in KFHMB's products selection, rather than the agency of the individual organization (or the transnational force of the KFH Group). However, KFHMB did not merely follow or imitate the practices of local counterparts: rather, as a result of the dilemma arising between its ideal versus the Malaysian market force, it eventually chose the same practice as the local banks. Thus, I argue that in Islamic banking, where banks need to work closely with the customers and other market participants (e.g., car dealers) rather than behave as a mere money lender, locally institutionalized market logics - rather than an individual bank's creativity-are likely to predominate in banks' behavior.

This study did not deeply examine the transnational nature of commodity Murabahah (CM) transactions, nor did it look into their cultural and social impacts on Malaysian Islamic banking. However, it would be valuable to explore local perceptions of this universal transaction and redefine its cultural meaning in the local context. Watson 
(2006 [1997]) stresses the importance of the internal meaning of "transnational phenomena" (i.e., content) within its global appearance (i.e., form). This thinking can be used to distinguish the internal meaning of CM in Malaysia from the transaction form itself, and, by making this distinction, one can understand the cultural diversity of transnational Islamic transactions.

Finally, considering KFHMB's dilemma concerning its ideals versus market realities, the current study stresses the importance of examining ethnographically Islamic banks' process of adapting to foreign markets. Especially important in this examination is the practitioners' decision-making process concerning product selection. From the mid2000s, ethnographic studies in Islamic banking and finance began to be observed (e.g., Maurer 2006). A significant contribution to the literature is Rudnyckyj (2017), who sheds light on the actors of Islamic banking and their narrative, and seeks to explore how actors themselves "are posing the problem of the alternative potential of Islamic finance" to conventional finance (2017: 273). Similarly, economic geographers stress the importance of the role of actors in understanding the mechanism of Islamic banking and finance (e.g., Pollard and Samers 2013; Poon et al. 2018). However, despite the recent rise of scholarly attention to ethnographic inquiry and the actors of Islamic banking, few studies have explored the social processes through which practitioners assemble a banking product from available options in a local market environment. An ethnographic inquiry that emphatically situates product development within an appropriate context will be able to clarify how Islamic bankers reconcile their religious ideals with market demand, thereby allowing us to reconsider the regional differences between Malaysia and the Middle East.

\section{References}

Abdul Ghani, B., and Hussain, S.A. 2007. Islamic Debt as the Global Propeller. In: Islamic Finance News Guide 2007, pp. 21-28. Kuala Lumpur: Redmoney.

Abdul Rahman, H., Alashwal, A.M., Ayub, M., and Abdullah, A.A. 2013. Abandoned Housing Projects in Malaysia: Pressing Issues during the Rehabilitation Process. International Journal of Architectural Research, 7 (1): 65-73.

Anonymous. 2010. KFH to focus on consumer banking. New Straits Times May 1, 2010.

Anonymous. 2018. KPKT finding solutions for abandoned housing projects. EdgeProp September 7, 2018.

https://www.edgeprop.my/content/1421438/kpkt-finding-solutions- 
abandoned-housing-projects. Accessed October 6, 2018.

Asutay, M. 2012. Conceptualising and Locating the Social Failure of Islamic Finance: Aspirations of Islamic Moral Economy vs the Realities of Islamic Finance. Asian and African Area Studies, 11 (2): 93-113.

Balala, M.H. 2011. Islamic Finance and Law: Theory and Practice in a Globalized World. London: I.B.Tauris.

Bank Negara Malaysia. 2006. Annual Report 2005. Kuala Lumpur: Bank Negara Malaysia.

Bank Negara Malaysia. 2007. Bank Negara Malaysia Signs Commodity Murabahah Agreement with Saudi Hollandi Bank. Press Release, May 17, 2007. Reference No. 05/07/06.

http://www.bnm.gov.my/index.php?ch=en press\&pg=en press\&ac=706 \&lang=en. Accessed June 9, 2018.

Bank Negara Malaysia. 2010. Shariah Resolutions in Islamic Finance: Second Edition. Kuala Lumpur: Bank Negara Malaysia.

Bank Negara Malaysia. 2012. Implementation of Shariah Advisory Council of Bank Negara Malaysia's Resolution on Bai' Inah. Circular, December 19, 2012. Reference No. BNM/RH/CIR 008-21.

https://islamicbankers.files.wordpress.com/2013/12/20121219implementation-of-shariah-advisory-council-of-bank-negara-malaysiasresolution-on-bai-inah.pdf. Accessed April 2, 2017.

Bouyamourn, A. 2016. UAE Cabinet approves Sharia Authority launch. The National May 8, 2016. https://www.thenational.ae/business/uaecabinet-approves-sharia-authority-launch-1.202169. Accessed March 21, 2018.

Chong, B.S., and Liu, M.H. 2009. Islamic Banking: Interest-free or Interestbased? Pacific-Basin Finance Journal, 17: 125-144.

https://doi.org/10.1016/j.pacfin.2007.12.003

Fligstein, N., and McAdam, D. 2012. A Theory of Fields. Oxford: Oxford University Press.

https://doi.org/10.1093/acprof:oso/9780199859948.001.0001

Granovetter, M. 2017. Society and Economy: Framework and Principles. Cambridge, Massachusetts: The Belknap Press of Harvard University Press.

Haron, S., and Shanmugam, B. 1997. Islamic Banking System: Concepts and Applications. Petaling Jaya, Malaysia: Pelanduk Publications.

Hasan, Z. 2011. A Survey on Shari'ah Governance Practices in Malaysia, GCC Countries and the UK - Critical Appraisal. International Journal of Islamic and Middle Eastern Finance and Management, 4 (1): 30-51. https://doi.org/10.1108/17538391111122195 
Islam, R., Abdul Ghani, A.B., Kusuma, B., and Teh Yew Hong, E. 2016. An Analysis of Factors that Affecting the Number of Car Sales in Malaysia. International Review of Management and Marketing, 6 (4): 872-882.

Ismon, N.Y. 2012. Legality of Tawarruq in Islamic Finance. Tazkia Islamic Finance and Business Review, 7 (1): 81-108.

Ismail, S., Azmi, F., and Thurasamy, R. 2014. Selection criteria for Islamic home financing in Malaysia. International Journal of Business and Society, 15 (1): 97-110.

Khan, M.M., and Bhatti, M.I. 2008. Islamic Banking and Finance: on its Way to Globalization. Managerial Finance, 34 (10): 708-725.

https://doi.org/10.1108/03074350810891029

Kuwait Finance House. 1981. Annual Report: Kuwait Finance House K.S.C 1980. Kuwait: Kuwait Finance House.

Kuwait Finance House. 2010. Annual Report: Kuwait Finance House K.S.C. and Subsidiaries 2009. Kuwait: Kuwait Finance House.

Lai, J. 2015. Industrial Policy and Islamic Finance. New Political Economy, 20(2): 178-198. https://doi.org/10.1080/13563467.2014.914159

Laldin, M.A., Abdul Khir, M.F., and Parid, N.M. 2012. Fatwas in Islamic Banking: A Comparative Study between Malaysia and Gulf Cooperation Council (GCC) Countries. ISRA (International Shari'ah Research Academy for Islamic Finance) Research Paper, 31.

Leutert, H.G., and Südhoff, R. 1999. Technology Capacity Building in the Malaysian Automotive Industry. In: K.S. Jomo, F. Greg, and R. Rajah (eds.) Industrial Technology Development in Malaysia: Industry and firm studies, pp. 247-273. London: Routledge.

Mahayudin, I., Ali, N., and Abdul Rahman, R. 2014. Islamic Banking Operations: The Malaysian Experience. Selangor, Malaysia: UiTM Press.

Mahmud al-Awan, M.M. 2008. Differences in Shariah Interpretations: The Impact on Islamic Financial Industry. In: Islamic Banking and Finance Institute Malaysia (IBFIM) (ed.), Contemporary Issues in Islamic Finance: Deliberation at the International Shariah Scholars Dialogue 2006, pp.3542. Kuala Lumpur: Bank Negara Malaysia.

Mansour, W., Jedidia, K.B., and Majdoub, J. 2015. How Ethical is Islamic Banking in the Light of the Objectives of Islamic Law?. Journal of Religious Ethics, 43 (1): 51-77. https://doi.org/10.1111/jore.12086

Maurer, B. 2006. Pious Property: Islamic Mortgages in the United States. New York: Russell Sage Foundation.

Meera, A.K.M., and Abdul Razak, D. 2005. Islamic Home Financing through Musharakah Mutanaqisah and Al-Bay' Bithaman Ajil Contracts: A Comparative Analysis. Review of Islamic Economics, 9 (2): 5-30. 
Meera, A.K.M., and Abdul Razak, D. 2009. Home Financing through the Musharakah Mutanaqisah Contracts: Some Practical Issues. Islamic Economics, 22 (1): 121-143. https://doi.org/10.4197/Islec.22-1.1

Mohd Subky, K.H., Liu, J.Y., Abdullah, M., Mokhtar, Z.F., and Faizrakhman, A. 2017. The Implication of Musharakah Mutanaqisah in Malaysian Islamic Banking Arena: A Perspective on Legal Documentation. International Journal of Management and Applied Research, 4 (1): 17-30. https://doi.org/10.18646/2056.41.17-003

Muhammad, A.H. 2008. Differences of Opinion and Fatwa in Shariah Rulings: The Impact on Islamic Financial Industry. In: Islamic Banking and Finance Institute Malaysia (IBFIM) (ed.), Contemporary Issues in Islamic Finance: Deliberation at the International Shariah Scholars Dialogue 2006, pp.43-74. Kuala Lumpur: Bank Negara Malaysia.

Nagaoka, S. 2007. Beyond the Theoretical Dichotomy in Islamic Finance: Analytical Reflections on Murabahah Contracts and Islamic Debt Securities. Kyoto Bulletin of Islamic Area Studies, 1 (2): 72-91.

Nagaoka, S. 2008. From Regional Diversity to Transregional Integration: A Study on Short-Term Liquidity Instruments (Inah and Tawarruq) in Islamic Finance [イーナとタワッルクからみた現代イスラーム金融のダ イナミズムー地域的多元性から東西市場の融合へ]. Kyoto Bulletin of Islamic Area Studies, 2 (1): 163-182.

Pollard, J., and Samers, M. 2013. Governing Islamic Finance: Territory, Agency, and the Making of Cosmopolitan Financial Geographies. Annals of the Association of American Geographers, 103 (3): 710-726.

https://doi.org/10.1080/00045608.2011.628256

Poon, J.P.H., Pollard, J., Chow, Y.W., and Ewers, M. 2017. The Rise of Kuala Lumpur as an Islamic Financial Frontier. Journal of Regional Studies, 51 (10): 1443-1453. https://doi.org/10.1080/00343404.2016.1214254

Poon, J.P.H., Pollard, J., and Chow, Y.W. 2018. Resetting Neoliberal Values: Lawmaking in Malaysia's Islamic Finance. Annals of American Association of Geographers, 108 (5): 1442-1456.

https://doi.org/10.1080/24694452.2018.1439723

Rosly, S.A. 2005. Critical Issues on Islamic Banking and Financial Markets: Islamic Economics, Banking and Finance, Investments, Takaful and Financial Planning. Indiana: AuthorHouse.

Rosly, S.A. 2017. Performance of Foreign Islamic Banks in Malaysia. In: M. Ariff (ed.) Islamic Finance in Malayisia: Growth and Development, pp. 115149. Kuala Lumpur: Pearson Malaysia.

Rudnyckyj, D. 2017. Subjects of Debt: Financial Subjectification and Collaborative Risk in Malaysian Islamic Finance. American Anthropologist, 119 (2): 269-283. https://doi.org/10.1111/aman.12861

Shuib, M.S., Sulaiman, A.A., and Mohamad, M.T. 2011. Middle East Bank 
and their Challenge operation in Malaysia: A Case study on Kuwait Finance House Malaysia Berhad. African Journal of Business Management, 5 (11): 4000-4006.

Smith, K. 2004. The Kuwait Finance House and the Islamization of Public Life in Kuwait. In: C.M. Henry, and R. Wilson (eds.) The Politics of Islamic Finance, pp.168-190. Edinburgh: Edinburgh University Press. https://doi.org/10.3366/edinburgh/9780748618361.003.0008

Smolo, E., and Hassan, M.K. 2011. The potentials of musha-rakah mutana-qisah for Islamic housing finance. International Journal of Islamic and Middle Eastern Finance and Management, 4 (3): 237-258.

https://doi.org/10.1108/17538391111166476

The Central Bank of Kuwait. 2005. The Legal Issues in the Islamic Financial Services Industry. Presented at the Legal Issues in the Islamic Financial Services Industry.

http://www.cbk.gov.kw/en/assets/pdfs/speech-01-03-2005-10-30761.pdf. Accessed October 10, 2018.

The Central Bank of Kuwait. 2007. Development \& Integration of Islamic Finance, keynote speech at the opening of the 1st Annual World Islamic Finance \& Investment Conference (WIFI) in the State of Kuwait, March 4-5, 2007. http://www.cbk.gov.kw/en/statistics-andpublication/publications/published-speeches.jsp. Accessed June 12, 2018.

Warde, I. 2000. Islamic Finance in the Global Economy. Edinburgh: Edinburgh University Press. https://doi.org/10.3366/edinburgh/9780748612161.001.0001 Watson, J.L. (ed.) 2006[1997]. Golden Arches East: McDonald's in East Asia. 2nd edition. Stanford, California: Stanford University Press.

Yousef, T.M. 2004. The Murabaha Syndrome in Islamic Finance: Laws, Institutions, and Politics. In: C.M. Henry, and R. Wilson (eds.) The Politics of Islamic Finance, pp.63-80. Edinburgh: Edinburgh University Press. https://doi.org/10.3366/edinburgh/9780748618361.003.0003

Zaher, T.S., and Hassan, M.K. 2001. A Comparative Literature Survey of Islamic Finance and Banking. Financial Markets, Institutions \& Instruments, 10 (4): 155-199. https://doi.org/10.1111/1468-0416.00044 
Hideki Kitamura is a postgraduate student at Institute of Ethnic Studies (KITA), The National University of Malaysia (UKM). The National University of Malaysia [Universiti Kebangsaan Malaysia], Institute of Ethnic Studies. Bangi, Selangor, 43600, Malaysia. Compliance with Ethical Standards: got the permission of disclosure of informants' interview data. No financial support for this paper. 